\title{
Promoting Biofuels Adoption in Nigeria: A Review of Socio-economic Drivers and Incentives
}

\author{
Nelson Abila \\ Department of Industrial Management, University of Vaasa \\ P.O. Box 700, 65101 Vaasa, Finland \\ Tel: +35844 3177440,E-mail: nelson.abila@uwasa.fi
}

\begin{abstract}
The adoption of biofuels holds a diversity of opportunities and potentials for the Nigerian economy. Some of these opportunities are key socio-economic drivers and incentives promoting the increasing adoption of biofuels. From the upstream to the downstream sub-sectors, there is an increasing entry of players and participants (private and public investors). This paper explores the underlining socio-economic drivers and incentives promoting and encouraging more investments in the biofuels subsectors of the Nigerian economy. The research sourced data from basically secondary sources and through desk-reviews. The papers identifies essential socio-economic indices which include the default dependence of biomass fuels, poverty and unemployment, declining agricultural productivity, underutilization of arable lands, potential demand for biofuels and government policy and incentives. As the global trend shows increasing adoption of biofuels, this paper reveals and discusses the socio-economic drivers peculiar to Nigeria. These key factors identified are issues to put into consideration for sustainably managing biofuels investments in Nigeria. Some of these factors present prospects and problems requiring medium and long term policy interventions from government to ensure an efficient transition into a bioenergy driven economy. The socio-economic factors identified also presents key variables for further socio-economic and bio-economic modelling studies focusing on Nigeria.
\end{abstract}

Keywords: Biofuels, Drivers, Incentives, Policy, Bioenergy, Economy.

\section{Introduction}

This paper explores the underlining socio-economic drivers and incentives promoting and encouraging the investments and participations in biofuels adoption, development and utilization in Nigeria. Nigeria joined other nations in the quest for adopting biofuels as the continuous reliance on the fossil fuels continues to receive criticism and fire from scientists, activists, and a wide range of peoples and interests promoting and implementing a shift in energy sources to more clean and environmentally friendly options. The global cries for renewable alternatives energy sources combine with default potentials for large scale production of biofuels created the platform for Nigeria's gradual incursion into the biofuel era. Though Nigeria is a major petroleum exporting country $(1,2)$, the drivers and incentives for promoting biofuels adoption are deeply connected with the roots of the many problems impeding the growth and development of the nation's economy. There is a preponderance of rural communities and populations with a default energy reliance sourced mainly from renewable sources and primary biofuels such as fuelwood, charcoal, palm kernel shells, palmoil wastes (shaft and slurry), sawmill waste, cow dung among others. Though there is also a rapid growth of urban centers across Nigeria, majority of the population in urban areas also still depend on these renewable sources such as charcoal because of the very low rate of access to electricity, natural gas or other improved energy sources.

This paper identifies and explores the underlining socio-economic drivers, relative incentives as well as exogenous and endogenous inducements for promoting and encouraging more investments in the biofuels subsectors of the Nigerian economy. From the analysis, the paper presents a multilevel, multifactor and multi-actors framework that constitute the drivers for biofuels adoption in Nigeria. 


\section{Methodology}

This research is a review of the socio-economic and related factors that explain the default renewable energy dependence and stimulating the trend in the investments in the broader biofuels subsector ranging from feedstock production to biofuels refining and biofuels distributions networks across Nigeria. The research sourced data from basically secondary sources and through desk-reviews. This review work is limited by the inability to conduct primary survey and the attendant gaps in information. Secondary data are sourced from the Nigeria Bureau of Statistics reports and other available secondary sources including previous publications and report from the International Energy Agency. Data sourced were analysed using descriptive statistics. The paper also presents a preliminary framework for driver of biofuels.

\section{Biofuel Development in Nigeria}

\subsection{Biofuels in Nigeria}

Though the traditional energy sources in Nigeria are predominantly combustible renewable fuels (3), there is an increasing shift and adoption of the first and second generation biofuels. The first generation biofuels which include biodiesel, bioethanol and biogas (4) are sourced mainly from edibles sources or current food material such as maize, soyabean, sugarcane, cassava for ethanol or oil production which can also be used as energy sources after further processing. The second generation biofuels which are fuels sourced from mainly non-edible sources such as jatropha, algae (4). A range of first generation biofuels are already being produce at small scales in Nigeria. Ethanol production is part of the traditional livelihood systems in the Niger Delta area and extending to some part of the south western States. Various individual and public investment projects in first generation biofuels are taking up in various part of Nigeria. These investment projects are at various stages of implementation ranging from feasibility studies to refinery plant installation. Progress have been reported in the designing of biogas plants at the Usman Danfodiyo University where a biogas digester with 425 litres capacity adequate for household cooking energy need has been developed (5). Other experimental efforts are also ongoing at the University of Nigeria, Nsukka and at the Global Network for Environment and Economic Development Research (GNEEDER) in Ibadan. Nigeria import about 4.5 tonnes of motor gasoline in 2008 (6) from refineries in countries which are already blending the fuels according to their blending regimes. There is no information on the blending rate of fuel used in Nigeria sourced from imports or refined locally.

\subsection{Nigerian Biofuel Policy and Incentives}

In promoting biofuels, the government in 2005 gave the Automotive Biomass Program for Nigeria directive to the Nigerian National Petroleum Corporation (NNPC) to facilitate the adoption on biofuels and promote investment in the sector. This led to the birth of the Nigerian biofuel policy and incentives (7), a government whitepaper for promoting biofuels in Nigeria. The white papers provide a broad policy platform for promoting the adoption of biofuels and for fast tracking the investment in biofuels value chain from feedstock production to biofuel refining and distribution. It set a target of 10 years for attaining full E-10 blending of gasoline and by implication B-10 for diesel. Though the whitepaper identified very few source of biofuels feedstock in Nigeria particularly for producing first generation biofuels, Nigeria has the potential for producing feedstocks for second generation biofuels including jatropha, algae and Shea nut. The underlining objectives for government interest in a national biofuel promotion are among other revenue diversification, job creation, improving agricultural productivity, meeting energy needs as well as deriving environmental benefits. 


\section{Drivers of Biofuels Adoption}

\subsection{Default dependence on renewable biomass fuels}

International Energy Agency (3) estimates put the total energy consumption for Nigeria at 4 Quadrillion Btu or 107,000 kilotons of oil equivalent. This IEA estimate shows that combustible renewable fuels providing 80.2 percent of the total energy need. According to the IEA report, the highest contribution for renewable biomass fuels serves the energy requirements for heating, and cooking needs particularly in the rural areas where access to the national grid is currently not available or still a dream in the pipeline. A previous national survey of the National Bureau of Statistics - NBS in 2005 which profiled the poverty level in Nigeria provided national estimate of the sources fuel for cooking as shown in Figure 1. Firewood contributed nearly 70 percent based on this estimate (8). In 2007, an economic survey by the NBS shows there has a gradually climb in the proportion of the population of Nigeria who depend on fuelwood for cooking. NBS estimates put the proportion at 74.1 percent. Previous study (5) had also reported a 1991 energy source survey in which fuelwood contributes about 66 percent. The electricity supply and sources survey for the same year 2007 also indicated that only about 47 percent of the population access electricity from the main national grid while considerable proportion (41 percent) do not have access to any form electricity supply. IEA data for 2008 indicated that electrification rate for Nigeria was 47 percent for the entire country. In urban areas, 69 percent of the population had access to electricity compared to rural areas where electrification rates were 26 percent. Approximately 81 million people do not have access to electricity in Nigeria.

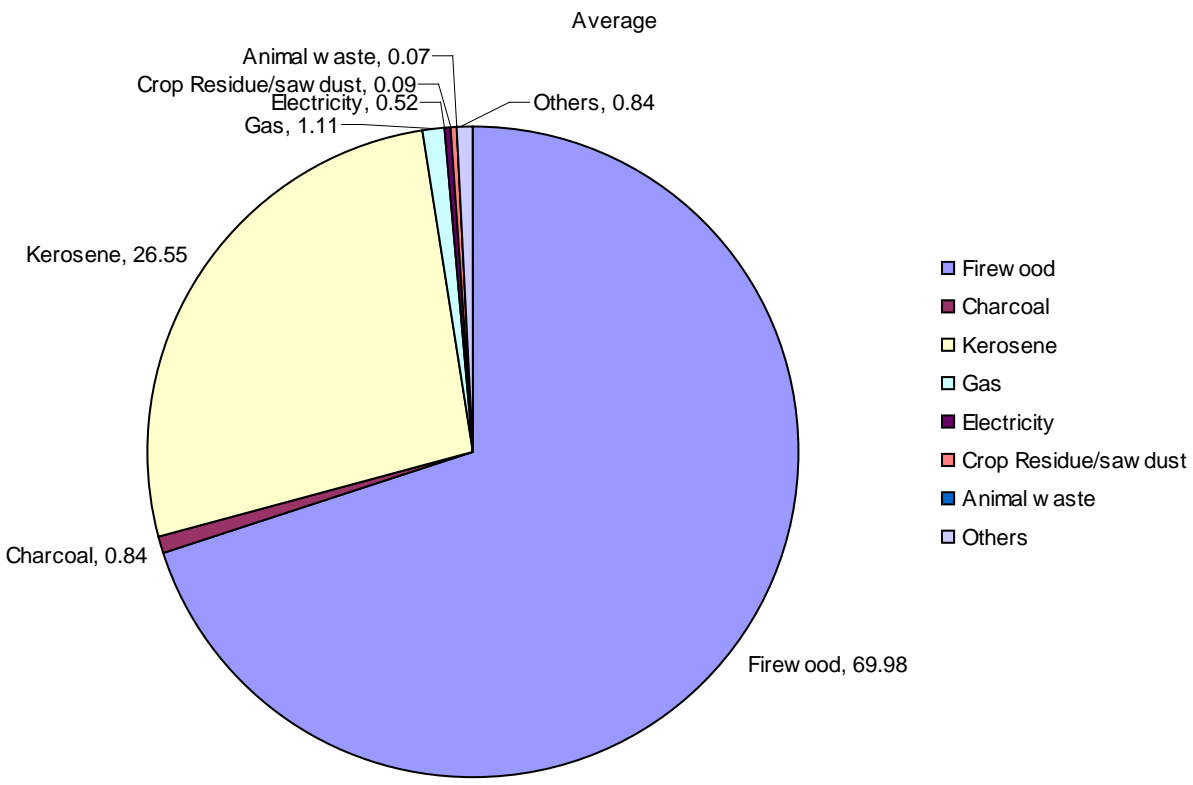

Fig. 1. Energy consumption by source in Nigeria (Source: NBS, 2007)

\subsection{Poverty and Unemployment}

The poverty level and unemployment rate in Nigeria and the declining capacity for electricity generation has deeply entrenched the dependence on renewable biomass fuels. The current level of poverty and the default reliance of energy from renewable source provide opportunity for a transition to improved technologies and techniques of using the traditional biofuels. The use of improved wood stoves and small family biogas initiatives, briquetting of sawdust and 
other agricultural waste in yet another option in promoting biofuels. Though the use of traditionally produced fuels of kernel oil or other oil as lighting reduced over the years, there is an opportunity to stimulate the local production of biodiesel for off-grid electricity for powering homes and appliances that are far from the national electricity grid infrastructure. Table 1 below shows the increasing poverty rate and incidence in Nigeria between 1980 and 2004. The increasing poverty level is an indicator of the lack of access to improved energy sources, an existing need and potential demand for alternatives such as biofuels.

Table 1. Trends in Poverty Levels between 1980 and 2004

\begin{tabular}{lcccc}
\hline Year & $\begin{array}{c}\text { Population } \\
\text { Estimate } \\
\text { (million) }\end{array}$ & $\begin{array}{c}\text { Poverty } \\
\text { Incidence } \\
(\%)\end{array}$ & $\begin{array}{c}\text { Rate of } \\
\text { Poverty } \\
\text { Increase }\end{array}$ & $\begin{array}{c}\text { Rate of } \\
\text { Population } \\
\text { Growth }\end{array}$ \\
\hline 1980 & 65 & 28.1 & 0 & 0 \\
1985 & 75 & 46.3 & 64.8 & 15.4 \\
1992 & 91.5 & 42.7 & -7.8 & 22.0 \\
1996 & 102.3 & 65.6 & 53.6 & 11.8 \\
2004 & 126.3 & 54.4 & -17.1 & 23.5 \\
\hline
\end{tabular}

\subsection{Potential Demand for biofuels}

The Nigerian Biofuel Policy and Incentive gave an estimate of fuel ethanol requirement at 10percent blending rate to be about 1.3 billion litres per annum with projected increase to 2 billion litres by 2020. This estimate gives the worth of the bio-ethanol market at a 30 percent less the price of gasoline to be $\$ 391$ million annually. Table 2 below shows the various substitution capacity for biofuels based on the 2008 average consumption of the petrol, household kerosene and diesel. A combined capacity for the major fuels consumption at the blending rate 10-percent proposed by the Nigerian biofuels policy gives a demand of $2.8 \mathrm{mt}$ of biofuels.

Table 2. Nigeria's Biofuel substitution capacity on 5, 10, 20, 30 percent fuels blending rates ('000 mt)

Fuel Types Yearly Biofuels substitution capacity for blending rates
Average

Consumption

\begin{tabular}{cccccc} 
& ('000 mt) & $\mathbf{5}$ & $\mathbf{1 0}$ & $\mathbf{2 0}$ & $\mathbf{3 0}$ \\
\hline PMS & $20,822.45$ & 1041.12 & 2082.25 & 4164.49 & 6246.74 \\
HHK & $3,766.13$ & 188.31 & 376.61 & 753.23 & 1129.84 \\
AGO & $5,524.94$ & 276.25 & 552.49 & 1104.99 & 1657.48
\end{tabular}

PMS - Premium Motor Spirit (Petrol), HHK - Household Kerosene, AGO - Automotive Gas Oil (Diesel)

\subsection{Feedstocks production and productivity improvement}

Nigeria falls with the region of the world rated to have high potential for biofuel production based on the three-criterion of the level water availability, level of available arable land and the state of food insecurity (10). This high potential is further buttressed by the current production capacity for the basic feedstocks for first generation biofuels. The argument for improving the level of productivity of crops with very high potentials and currently command a high demand for biofuel production was made in previous study (2). Table 3 shows the key crops for which Nigeria ranked between first and twentieth position in terms of nominal 
production globally. The ranking of productivity per hectare cultivated for this crops shows Nigeria has much room for improving on productivity of these crops. The data shows even for cassava for which Nigeria leads in the production globally, the country ranks $13^{\text {th }}$ globally in terms of productivity per hectare cultivated. This underpins one of the underlining objectives for promoting crops based biofuels investment in Nigeria. The Nigerian biofuels policy classified investments with the biofuels value chain as an agro-allied sector to benefit from various incentives such as government guaranteed insurance, long term loans, value added tax waiver and custom duties waiver in attempt to stimulate biofuels production for achieving multi-objectives.

Table 3. Nigeria's production, productivity and cultivated area ranking for edible feedstocks

\begin{tabular}{|c|c|c|c|c|}
\hline Crop & $\begin{array}{c}2008 \text { Average } \\
\text { Yield (MT) }\end{array}$ & $\begin{array}{c}\text { Nigeria’s } \\
\text { Nominal } \\
\text { Production Rank } \\
\text { (Global) }\end{array}$ & $\begin{array}{l}\text { Nigeria’s Yield } \\
\text { (land } \\
\text { productivity) } \\
\text { Rank (Global) }\end{array}$ & $\begin{array}{c}\text { Nigeria's } \\
\text { Cultivated Area } \\
\text { (Ha) Rank }\end{array}$ \\
\hline Sesame & 110000 & 7th & $13^{\text {th }}$ & $6^{\text {th }}$ \\
\hline Palm fruits & 8500000 & 4th & $20^{\text {th }}$ & $3^{r d}$ \\
\hline Ground Nut & 3900000 & 3rd & $6^{\text {th }}$ & $3^{r d}$ \\
\hline Soybean & 591000 & 13th & $20^{\text {th }}$ & $10^{t h}$ \\
\hline Coconut & 234000 & 19th & $10^{\text {th }}$ & $17^{\text {th }}$ \\
\hline Cotton Seed & 492000 & 12th & $18^{\text {th }}$ & $9^{\text {th }}$ \\
\hline Cassava & 44582000 & $1 s t$ & $13^{\text {th }}$ & $1^{\text {st }}$ \\
\hline Maize & 7525000 & 14th & $17^{\text {th }}$ & $7^{\text {th }}$ \\
\hline Maize Green & 5709000 & $3 r d$ & $17^{\text {th }}$ & $2^{\text {nd }}$ \\
\hline
\end{tabular}

Source: Adapted from Food and Agriculture (FAO) Statistics 2008

\section{Framework for Biofuels Adoption in Nigeria}

The review of available literatures, the adopted National policy on biofuels and incentives brought to the fore key drivers promoting biofuels adoption in Nigeria. Figure 2 shows a multilevel, multifactor and multi-actors framework that constitute the drivers for biofuels adoption in Nigeria. On the government side are exogenous and endogenous inducements which brought about the development of biofuel policies and laws, incentives and investment funds for driving the national Automotive Biomass Programme for Nigeria. The government whitepaper target the private sectors and other players including State governments, cooperative groups and associations for the economic, environmental, socio-cultural and technical and infrastructural benefits which the increase in the biofuels investments will bring to the country. 


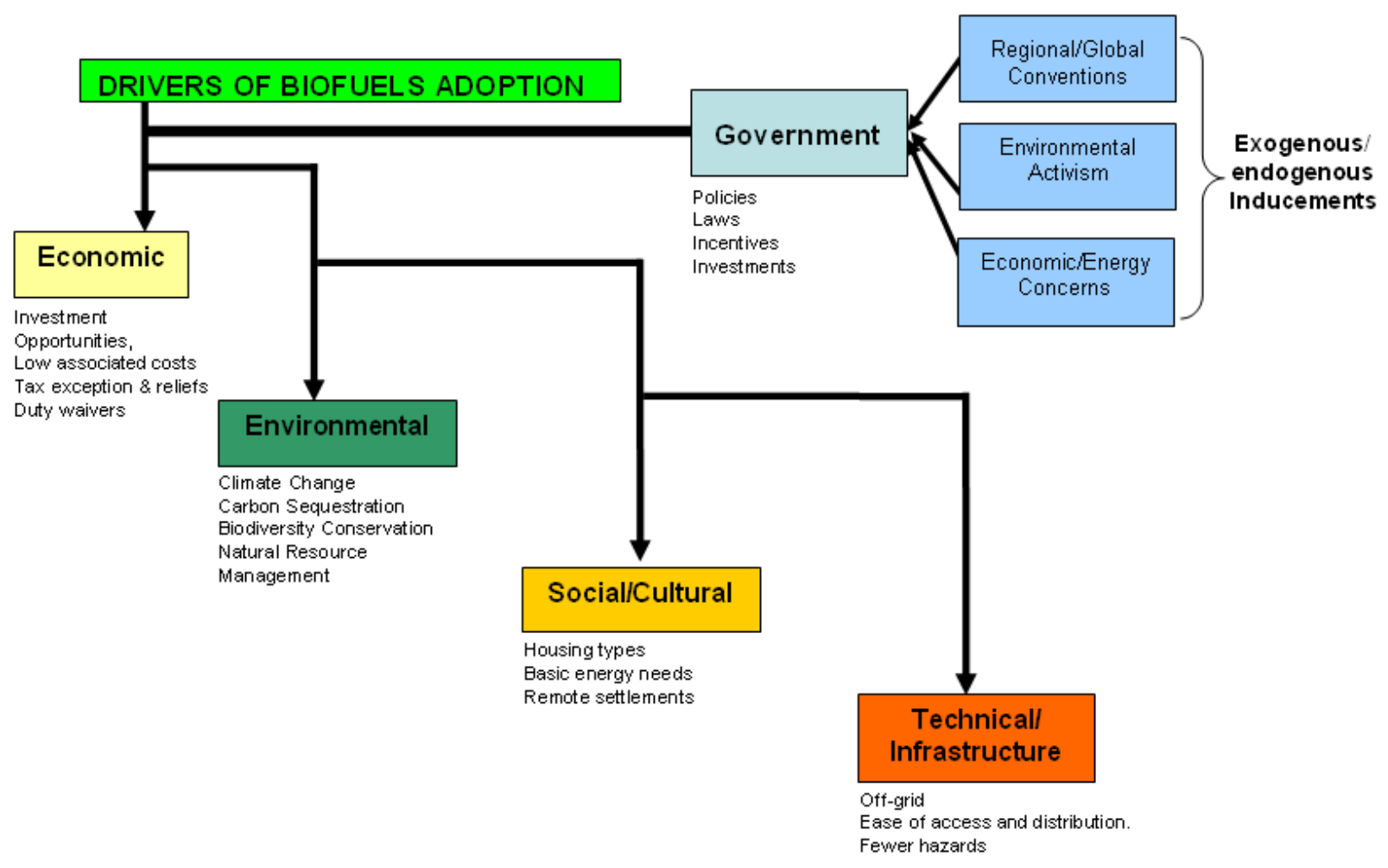

Fig. 2: Framework of biofuels adoption in Nigeria

\section{Conclusion}

This paper attempted to highlight some of the key drivers of biofuels adoption in Nigeria. The current dependence on renewable biomass fuels, poverty level, unemployment and the existing lack of access to improve energy sources are evidences of the existing gap in energy supply. This gap provides a strong incentives for attracting investment in biofuel production value chain considering the enabling environment and incentives created by the government. The multilevel framework on biofuels adoption identified the key drivers and the underlining motivations. The drivers which are peculiar to the Nigerian socio-economic condition hold the key to the nation's capability to be a major player in the increasing global biofuels market. These key factors identified are issues to put into consideration for sustainably managing biofuels investments in Nigeria. Some of these factors present prospects and problems requiring medium and long term policy interventions from government to ensure an efficient transition into a bioenergy driven economy. The socio-economic factors identified also presents key variables for further socio-economic and bio-economic modelling studies focusing on Nigeria. The framework provides a pillar for further analysis of the relationship between actors, the drivers and motivations for biofuels adoption in Nigeria.

\section{Acknowledgement}

This article is part of an ongoing doctoral research on bio-economic and environmental modeling of biofuels adoption in the energy sector in Nigeria and Finland. The funding for the research comes from the FORTUM Foundation and the Evald and Hilda Nissi Foundation. 


\section{References}

[1] A.S. Sambo, Strategic Developments in renewable energy in Nigeria, Newsletter of the International Association for Energy Economics, Third Quarter 2009, pp. 15-19 available at www.iaee.org/en/publications/newsletterdl.aspx?id=75 sited 12 October 2010.

[2] N. Abila, Biofuels adoption in Nigeria: a preliminary review of feedstock and fuel production potentials, Management of Environmental Quality: An International Journal Vol. 21, No 6, 2010. pp. 785-795.

[3] International Energy Agency (IEA), 2007 Energy Statistics available at http://www.iea.org/statist/index.htm sited 14 October 2010.

[4] S.N. Naik, Vaibhav V. Goud, Prasant K. Rout, Ajay K. Dalai, Production of first and second generation biofuels: a comprehensive review, Renewable and Sustainable Energy Reviews, Volume 14, Issue 2, February 2010, pp. 578-597

[5] J. F. K. Akinbami, M.O. Ilori and I.O. Oyebisi, Biogas enegy use in Nigeria: current status, future prospects and policy implications. Renewable and Sustainable Energy Reviews Vol 5, 2001, pp. 97-112.

[6] International Energy Agency (IEA). 2008 IEA Energy Statistics available at http://www.iea.org/statist/index.htm sited 20 October 2010.

[7] Nigerian National Petroleum Corporation (NNPC), Nigerian Biofuel Policy and Incentives.

[8] National Bureau of Statistics (NBS) 2005. Poverty Profile for Nigeria. Federal Republic of Nigeria

[9] National Bureau of Statistics (NBS) 2007. Social Statistics in Nigeria. Federal Republic of Nigeria

[10]J. von Braun, "When food makes fuel: the promises and challenges of biofuels", keynote speech at the Crawford Fund Annual Conference, 2007, Melbourne. 